\title{
ANALYZES OF ANTIPLATELETS AND ANTICOAGULANTS UTILIZATION IN PATIENTS TREATED IN CARDIOVASCULAR REHABILITATION CENTER FROM CROATIA
}

\author{
Boban Marko, ${ }^{1,2}$ Persic Viktor, ${ }^{1,2}$ Pesa Vladimir, ${ }^{1}$ Pehar-Pejcinovic Vesna, ${ }^{1}$ Detanac S. Dzemail, ${ }^{3}$ \\ Sipic Tomislav, ${ }^{2}$ Zulj Marinko, ${ }^{2}$ Franovic Tamara, ${ }^{1}$ Vcev Aleksandar ${ }^{2}$ \\ 'Department of cardiology, University hospital "Thalassotherapia Opatija", \\ Medical faculty University of Rijeka; Croatia \\ ${ }^{2}$ Department of internal medicine, Medical faculty JJ Strossmayer, Osijek, Croatia \\ ${ }^{3}$ General hospital Novi Pazar, Serbia
}

Primljen/Received 31. 03. 2016. god.

Abstract: Purpose: Discordance with the guidelines and underutilization of pharmacotherapy for secondary prevention frequently exists in clinical practice. Aim of our study was to assess the prescription routine and drug utilization patterns for antiplatelets and peroral anticoagulants in tertiary medical center specialized for cardiovascular rehabilitation.

Methods: study included 96 consecutive patients scheduled for cardiovascular rehabilitation in period 1-6 months after the acute treatment for ischemic 87 $(80.2 \%)$ and valvular heart disease 18 (19.8\%). Patients were divided according to etiology of heart disease and type of acute cardiovascular treatments (conservative, percutaneous coronary interventions (PCI) and surgery).

Results: Dual antiplatelet therapy was the most commonly applied regimen in $84(87.5 \%)$ of conservatively treated myocardial infarctions, $47(61.9 \%)$ of percutaneous coronary interventions (PCI) and 13 $(58.9 \%)$ of surgically treated group $(p>0.05)$. Among studied group of patients significant differences in utilization were found for warfarin, or combinations of antiplatelets with warfarin $(\mathrm{p}<0.001)$, as well as studied etiologies of heart disease $(p<0.001)$, whilst there were no differences for those groups for studied antiplatelets drugs $(\mathrm{p}>0.05)$. All four of patients that received triple therapy $(4.17 \%)$ were from surgical group. Underutilization of antiplatelets in ischemic heart disease was at $11(14.3 \%)$ what was congruent with the developed industrial nations.

Conclusions: Acute cardiovascular treatment type, but not heart disease etiology, had significant influence
Prihvaćen/Accepted 20. 05. 2016. god.

on subsequent prescription routine. Decreased use of pharmacological agents for secondary prevention in surgical patients was revealed. Drug utilization analyzes can offer improvement in optimizing medical treatments, quality of care and decrease unnecessary polypragmasia, as well as improve economical efficiency of medical management.

Key words: drug utilization (DU) review; antiplatelets (AP); anticoagulants; warfarin; cardiovascular rehabilitation; ischemic heart disease; valvular heart disease.

\section{INTRODUCTION}

Antiplatelets (AP) and oral anticoagulants (OA) make inevitable components of successful long term management of various atherosclerotic born diseases (1). Named groups are among the most frequently prescribed therapy in prolonged course worldwide, thanks to efficiency in prevention of thrombogenic complications through primary, secondary or tertiary settings (2). However, occurrence of re-thrombosis is still not completely diminished by monotherapeutic approach, even with optimally selected dosage and treatment duration (3). Dual antiplatelet therapy using acetylsalicylate and thienopyridine considerably improves those outcomes, in terms of rate of major cardiovascular complications (4). Overall risk for developing major thrombotic complications on the other hand is becoming excessively increased, due to multifaceted relations. Complex associations include growth in number of population with earlier cardiovascular treatments, burden of more than a few of chronic comorbidities, di- 
sease chronicity, as well as the ageing of population. The triple drug regimens, comprising from anticoagulant and two antiplatelets, were introduced for secondary and tertiary prevention of casuistic with prominent pro-thrombotic risk (5). Although the antithrombogenic effect of triple combination is more powerful, at the same time the prevalence of clinically important bleedings is unpleasantly increased. Triple antithrombotic therapies are dominantly matter of debates in regard to ideal combinations of drugs, dosage titrations or duration.

Costs of health care for advanced atherosclerotic process (including cerebrovascular and ischemic heart disease) tend to be additionally increased, and of reverse relation with the continuous adherence to established preventive measures (2). Underutilization of pharmacological secondary prevention is frequently found in clinical practice; moreover it is responsible for differences in prevalence of cardiovascular diseases, morbidity or mortality, which are found between various nations (6). There is a relative lack of data in studies concerning applying of secondary preventive measures from transitional European countries. The aim of our study was to assess drug utilization patterns for antiplaelets and peroral anticoagulants in tertiary medical center specialized for cardiovascular rehabilitation from Croatia. Additionally, combined effects of antiplatelet-anticoagulant therapy were studied in relation with cardiovascular risk factors, comorbities and clinical diagnostics.

\section{PATIENTS AND METHODS}

This was phase IV, open, not randomized and not controlled investigation, having one treatment arm. It included patients scheduled for cardiovascular rehabilitation subsequent to treatment for ischemic or valvular heart disease. Indications coverage included patients after implantation of stent for acute coronary syndrome or chronic ischemic heart disease, as well as those with surgical revascularization for coronary artery disease, and patients with valvular surgery (primary procedure, or as combined procedure with surgical revascularization. Procedures included implantation of prosthetic valves (animal or synthetic), valvuloplastic (using ring, artificial cordes or other). Study timeline included period from 1-6 months after the acute treatments. Patients were examined by team of experienced specialists including internists, cardiologists and psychologist prior to inclusion. Diagnostics included medical history (evaluation of underlying chronic conditions, cardiovascular risk factors and relevant comorbidities), transthoracic echocardiography, anthropometrics, laboratory and electrocardiography. Medical history included evaluation of underlying chronic conditions, cardiovascular risk factors and relevant comorbidities. Population was analyzed through groups of cardiovascular acute treatments and structure of antiplatelets and anticoagulant therapy.

Patients with severe acute illness or chronic conditions considered as contraindications for cardiovascular rehabilitation were not included. Those namely were: unstable angina (acute and chronic of Canadian Cardiac society-CCS III to IV grade), hemodynamically significant pericardial effusion, decompensated heart failure (New York heart association-NYHA III and IV grade), hemodynamic instability, significant disorders of rhythms (ventricular fibrillation, sustained ventricular tachycardia, significant bradycardia in need for pacemaker), decompensated diabetes (untreated hyperglycemia, hypoglycemia, ketosis), thyroid disorders (untreated hyperthyreosis, hypotyreosis), significant acid base misbalance (acidosis or alkalosis), advanced or end stage respiratory disease (chronic obstructive disease of Global Initiative for Chronic Obstructive Lung Disease-GOLD III and IV grade, untreated asthma, pulmonary hypertension, pulmonary embolism, pleural effusion, pneumonia, active tuberculosis), acute febrile illnesses (sepsis, flu, urinary infections), end stage renal disease (in need for dialysis), malignant disease (untreated, being in remission for less than 2 years, metastatic cancer), edema (peripheral, ascites or anasarca), severe hematologic or rheostatic disorders (severe anemia, patients that had transfusion after the first postoperative week, pronounced increase or decrease of any type of blood cells i.e. leucopenia and leucosis, as well as others) and those with significant early postoperative surgical complications (wound dehiscence, renal failure, surgery scission-related bleeding, infection/sepsis).

\section{Main outcome measures}

Drug utilization analyzes: Prescription analyzes included prevalence of proton pump inhibitor, ACE-inhibitor/sartan, beta blocker, calcium antagonists, loop diuretic, antidiabetics, acetylsalicylate/thienopyridine and peroral anticoagulant i.e. warfarin. While quoted drugs use was assessed as therapeutic group, and there were no additional individual analyzes, the rate of specific antiplatelets, peroral anticoagulant and their combinations were analyzed. Psychoneuromodulatory therapy was not included in analyzes (anxiolytics, hypnotics).

Anthropometrics: Measurements of body weight were given in kilograms, height in meters and body mass index (BMI) calculated $\left(\mathrm{kg} / \mathrm{m}^{2}\right)$. Waist and hip circumferences (WC, HC) and ratios (WHR) were presented in centimeters. 
Laboratory diagnostics: Samples were taken in morning hors 07:30-08:30 AM in fasting patients. Routine comprised from: Complete blood count (CBC) with number of erythrocytes (ERC) multiplied by $10^{12}$, hematocrit (HCT) in $\mathrm{L} / \mathrm{L}$, mean corpuscular erythrocyte volume (MCV) in fL, number of platelets (PLT) multiplied by $10^{9}$; leukocyte count (LKC) multiplied by $10^{9}$. Biochemical analyzes comprised of alanine aminotransferase (ALT) in IU/L at $37^{\prime} \mathrm{C}$, aspartate aminotransferase (AST) in IU/L at $37^{\circ} \mathrm{C}$, gamma glutamyltransferase (GGT) in IU/L at $37^{\circ} \mathrm{C}$, serum glucose in $\mathrm{mmol} / \mathrm{L}$, total cholesterol (CHOL) in $\mathrm{mmol} / \mathrm{L}$, low density lipoprotein (LDL) in $\mathrm{mmol} / \mathrm{L}$, high density lipoprotein (HDL) in $\mathrm{mmol} / \mathrm{L}$, triglycerides $(\mathrm{TG})$ in $\mathrm{mmol} / \mathrm{L}$, creatinine $(\mathrm{CR})$ in $\mu \mathrm{mol} / \mathrm{L}$, urea in $\mathrm{mmol} / \mathrm{L}$, uric acid (UA) in $\mu \mathrm{mol} / \mathrm{L}$ and thyroid stimulating hormone in $\mathrm{mIU} / \mathrm{L}$.

Cardiovascular risk: assessment included prevalence of hypertension, hypercholesterolemia, chronic renal disease (CRD), treated diabetes mellitus, glucose intolerance, smoking history, chronic obstructive pulmonary disease, any disturbance of psychological profile (DPP), known atherosclerotic process and thrombosis (medical history of clinically overt peripheral artery disease, cerebrovascular stroke, carotid artery stenosis and pulmonary artery embolism), atrial fibrillation, past myocardial infarction, preserving of systolic function of the left ventricle (cutoff point set at 50\%).
Echocardiography: Transthoracic echocardiography assessments were done by two experienced cardiologists on Toshiba "Artida" equipped with $3 \mathrm{MHz}$ cardiology probe, following general recommendations by American Society for Echocardiography and European Association of cardiovascular imaging ${ }^{7}$.

Ethical issues: Study was approved by ethical committee of the University Hospital "Thalassotherapia Opatija" in line with the good clinical practice guidelines. Patients were included upon signing of written informed consent. There were no financial compensations, supports or grants for patients and authors engaged in the study. Study was not performed on behalf of any other parties than presented.

Statistical analyses: Population and groups were studied with descriptive statistic and presented as means and standard deviations. Population demographic, comorbidities, and nutritional risk screen was tested for differences with Chi square tests accordingly. Data on anthropometrics, laboratory, echocardiography and remainder numeric data were analyzed for differences by Mann-Whitney U test or Kruskal-Wallis ANOVA by ranks. Correlation of the anticoagulant or antiplatelets therapy with clinical diagnostics and outcomes was done by Spearman Rho. P value less than 0.05 was considered significant. Statistical analyses were done by experienced statistician using Statistica 10 for Windows and IBM-SPSS12 v20.

Table 1. Characteristics of the patient sample $(n=96)$ and studied groups

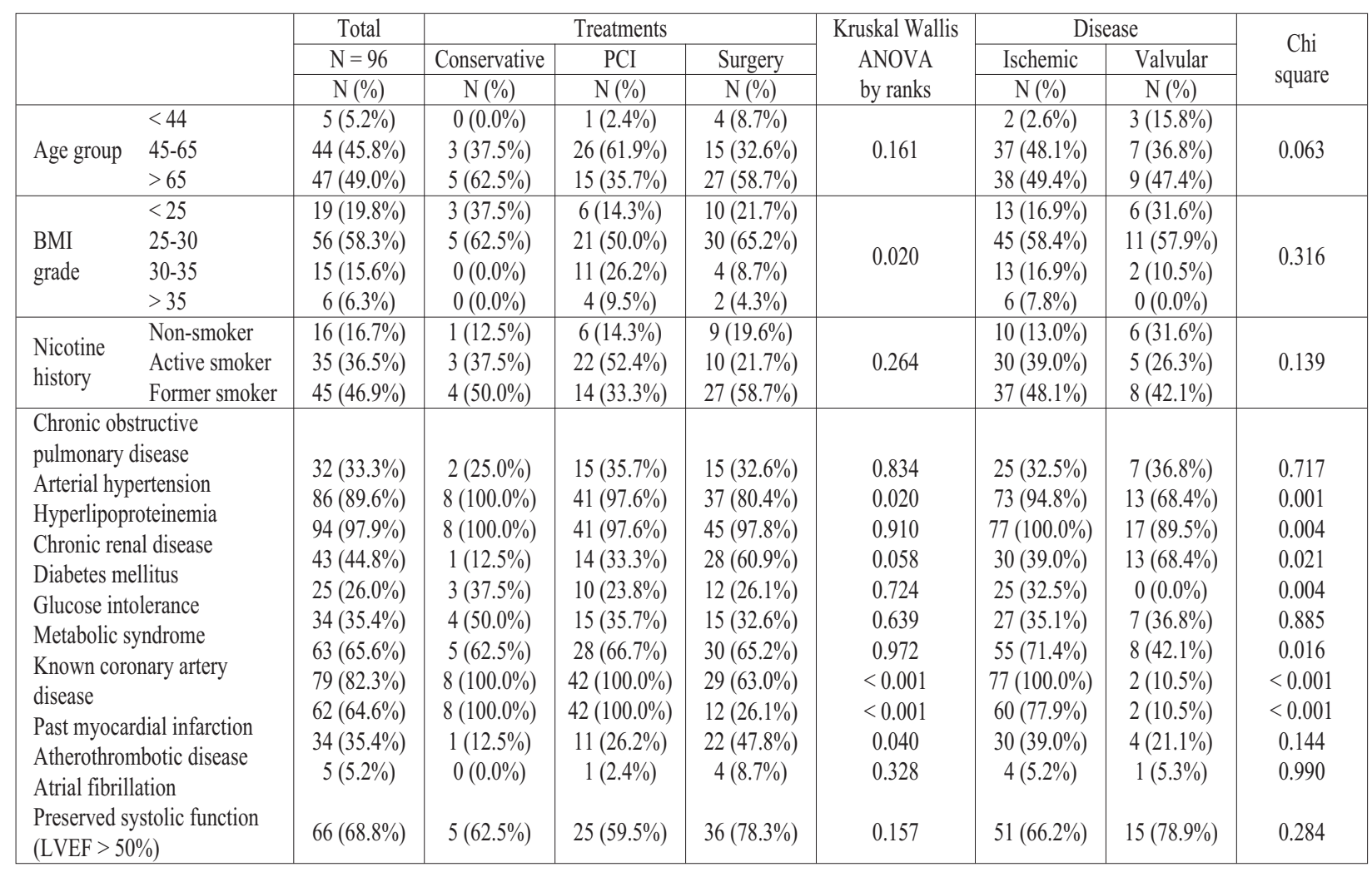

PCI - percutaneous coronary intervention; CABG — coronary artery bypass surgery; VS — valvular surgery; LVEF — left ventricle ejection fraction 


\section{RESULTS}

\section{Patients}

Mean age of patient was 63.1 years, with range 23-86. There was more of male patients, $70(72.9 \%)$, than female $26(27.1 \%)$. Patients were scheduled for cardiovascular rehabilitation in the timeline 1-6 months after heart surgery; median period at inclusion was 2.4 months. There were 77 patients $(80.2 \%)$ with acute treatment for ischemic heart disease and 18 (19.8\%) for valvular heart disease; with total of 46 (47.9\%) surgical treatments; 42 (43.8\%) percutaneous coronary interventions and $8(8.3 \%)$ of conservatively treated myocardial infarctions. Coronary artery bypass surgery (CABG) was performed in 28 patients $(29.2 \%)$, of which combined operation with valvular surgery (VS) was performed in $1(1.1 \%)$. Results of cardiovascular diagnostics among studied groups of patients are presented in the Table 1.

There were no patients with clinically overt acute gastrointestinal hemorrhage. There were no reports on dyspeptic symptoms within medical history, no recorded reflux esophagitis (verified by endoscopy).

\section{Cardiovascular diagnostics}

Differences in diagnostics among studied groups of acute treatment and etiologies of heart disease are presented in the Table 2, including the appraisal of clinical relevance.

\section{Antiplatelet and anticoagulant therapy}

Significant differences were found in use of antiplatelets (any AP agent) and previous treatments ( $\mathrm{p}<$ $0.001)$; in 36 (85.7\%) patients with PCI, 7 (87.5\%) of patients with conservative treatment and $30(65.2 \%)$ of surgically treated. Peroral anticoagulant (warfarin) therapy was used only in surgical patients, with prevalence of 24/46 (52.5\%). Significant difference was found on basis of heart disease etiology for prevalence of warfarin $8(10.4 \%)$ vs. $16(84.2 \%)$; $(\mathrm{p}<0.001)$ for ischemic and valvular backgrounds respectively. There

Table 2. Clinical diagnostics within studied groups of treatments and etiology of heart disease

\begin{tabular}{|c|c|c|c|c|c|c|c|c|}
\hline & Total & \multicolumn{3}{|c|}{ Treatments } & \multirow{3}{*}{$\begin{array}{l}\text { Kruskal } \\
\text { Wallis } \\
\text { ANOVA } \\
\text { by ranks }\end{array}$} & \multicolumn{2}{|c|}{ Disease } & \multirow{3}{*}{$\begin{array}{c}\text { Mann } \\
\text { Whitney } \\
\text { U test }\end{array}$} \\
\hline & \multirow{2}{*}{$\begin{array}{c}\mathrm{N}=96 \\
\text { Mean } \pm \mathrm{SD}\end{array}$} & Conservative & PCI & Surgery & & Ischemic & Valvular & \\
\hline & & Mean \pm SD & Mean \pm SD & Mean \pm SD & & Mean \pm SD & Mean \pm SD & \\
\hline $\mathrm{n}$ (coronary risk factors) & $6.2 \pm 1.6$ & $6.8 \pm 0.9$ & $6.8 \pm 1.2$ & $5.7 \pm 1.9$ & 0.018 & $6.7 \pm 1.2$ & $4.3 \pm 1.9$ & $<0.001$ \\
\hline Age (years) & $63.6 \pm 11.5$ & $70.0 \pm 11.5$ & $62.0 \pm 8.7$ & $64.0 \pm 13.4$ & 0.080 & $64.2 \pm 9.8$ & $61.0 \pm 16.8$ & 0.971 \\
\hline Height (m) & $1.70 \pm 0.10$ & $1.66 \pm 0.10$ & $1.67 \pm 0.08$ & $1.72 \pm 0.10$ & 0.024 & $1.69 \pm 0.09$ & $1.72 \pm 0.11$ & 0.639 \\
\hline Weight (kg) & $80.3 \pm 13.0$ & $73.2 \pm 12.8$ & $80.5 \pm 12.1$ & $81.2 \pm 13.7$ & 0.338 & $81.0 \pm 12.1$ & $77.4 \pm 16.3$ & 0.153 \\
\hline $\operatorname{BMI}\left(\mathrm{kg} / \mathrm{m}^{2}\right)$ & $27.9 \pm 3.7$ & $25.9 \pm 2.5$ & $28.9 \pm 3.9$ & $27.3 \pm 3.5$ & 0.028 & $28.3 \pm 3.7$ & $26.2 \pm 3.0$ & 0.012 \\
\hline Waist circumference (cm) & $100.7 \pm 9.1$ & $97.5 \pm 6.8$ & $101.9 \pm 9.8$ & $100.1 \pm 8.7$ & 0.348 & $101.6 \pm 8.8$ & $96.8 \pm 9.5$ & 0.065 \\
\hline Hip circumference (cm) & $101.9 \pm 11.4$ & $99.9 \pm 6.3$ & $104.0 \pm 6.6$ & $100.3 \pm 14.8$ & 0.146 & $103.1 \pm 6.4$ & $97.1 \pm 21.8$ & 0.242 \\
\hline $\operatorname{VHR}(\mathrm{n} / \mathrm{n})$ & $1.0 \pm 0.1$ & $0.98 \pm 0.08$ & $0.98 \pm 0.07$ & $0.98 \pm 0.07$ & 0.995 & $0.99 \pm 0.07$ & $0.95 \pm 0.07$ & 0.035 \\
\hline Erythrocytes count (n*1012) & $4.39 \pm 0.60$ & $4.45 \pm 0.56$ & $4.55 \pm 0.53$ & $4.23 \pm 0.64$ & 0.021 & $4.41 \pm 0.57$ & $4.31 \pm 0.73$ & 0.459 \\
\hline Hematrocryte $(n / n)$ & $0.39 \pm 0.05$ & $0.40 \pm 0.04$ & $0.41 \pm 0.04$ & $0.37 \pm 0.05$ & 0.005 & $0.39 \pm 0.05$ & $0.37 \pm 0.06$ & 0.104 \\
\hline Mean corpuscular volume (fL) & $88 \pm 11$ & $91 \pm 4$ & $88 \pm 10$ & $87 \pm 13$ & 0.498 & $88 \pm 12$ & $89 \pm 6$ & 0.937 \\
\hline Leukocytes (n*1012) & $7.93 \pm 2.47$ & $7.46 \pm 2.12$ & $7.87 \pm 2.35$ & $8.06 \pm 2.66$ & 0.896 & $8.06 \pm 2.43$ & $7.37 \pm 2.63$ & 0.208 \\
\hline Platelets (n*109) & $302 \pm 136$ & $278 \pm 113$ & $259 \pm 81$ & $346 \pm 165$ & 0.060 & $305 \pm 141$ & $287 \pm 114$ & 0.797 \\
\hline Glucose $(\mathrm{mmol} / \mathrm{L})$ & $6.5 \pm 1.2$ & $6.7 \pm 0.9$ & $6.5 \pm 1.4$ & $6.5 \pm 1.1$ & 0.635 & $6.7 \pm 1.3$ & $5.9 \pm 0.4$ & 0.008 \\
\hline Creatinine $(\mu \mathrm{mol} / \mathrm{L})$ & $114.1 \pm 49.6$ & $100.8 \pm 28.5$ & $111.1 \pm 58.4$ & $119.1 \pm 43.6$ & 0.032 & $114.5 \pm 54.5$ & $112.2 \pm 21.2$ & 0.187 \\
\hline Triglycerides (mmol/L) & $1.4 \pm 0.8$ & $1.52 \pm 0.70$ & $1.28 \pm 0.61$ & $1.59 \pm 0.98$ & 0.264 & $1.39 \pm 0.63$ & $1.68 \pm 1.35$ & 0.861 \\
\hline Cholesterol (mmol/L) & $4.3 \pm 1.2$ & $3.76 \pm 0.73$ & $3.93 \pm 1.23$ & $4.70 \pm 1.21$ & 0.002 & $4.07 \pm 1.13$ & $5.14 \pm 1.32$ & 0.001 \\
\hline HDL-cholesterol (mmol/L) & $0.9 \pm 0.4$ & $0.89 \pm 0.30$ & $0.95 \pm 0.32$ & $0.88 \pm 0.52$ & 0.526 & $0.88 \pm 0.34$ & $1.04 \pm 0.67$ & 0.390 \\
\hline LDL-cholesterol (mmol/L) & $2.2 \pm 1.1$ & $1.69 \pm 0.75$ & $1.96 \pm 1.18$ & $2.60 \pm 0.92$ & 0.001 & $2.10 \pm 1.08$ & $2.84 \pm 0.88$ & 0.002 \\
\hline AST (IU/L at 37’C) & $29.3 \pm 81.1$ & $21.63 \pm 8.02$ & $22.21 \pm 6.46$ & $37.07 \pm 117.19$ & 0.203 & $20.82 \pm 7.07$ & $63.58 \pm 181.63$ & 0.254 \\
\hline ALT (IU/L at $37^{\circ} \mathrm{C}$ & $36.9 \pm 52.3$ & $28.00 \pm 13.95$ & $32.05 \pm 17.46$ & $42.93 \pm 73.44$ & 0.896 & $31.64 \pm 16.50$ & $58.37 \pm 112.61$ & 0.613 \\
\hline GGT (IU/L at $37^{\prime} \mathrm{C}$ & $52.7 \pm 54.7$ & 35.38 & $43.21 \pm 31.08$ & $64.33 \pm 70.99$ & 0.100 & $51.74 \pm 53.19$ & $56.47 \pm 61.96$ & 0.626 \\
\hline LVEDd (mm) & $52.4 \pm 4.8$ & $52.0 \pm 6.4$ & $52.1 \pm 4.3$ & $52.8 \pm 5.0$ & 0.903 & $52.3 \pm 4.6$ & $52.8 \pm 5.7$ & 0.723 \\
\hline LVEF (\%) & $50.7 \pm 8.5$ & $47.5 \pm 12.0$ & $49.1 \pm 9.2$ & $52.8 \pm 6.6$ & 0.102 & $50.0 \pm 8.8$ & $53.6 \pm 6.6$ & 0.067 \\
\hline AV PG (mmHg) & $14.7 \pm 11.1$ & $12.3 \pm 5.5$ & $10.9 \pm 10.2$ & $18.4 \pm 11.5$ & 0.001 & $12.4 \pm 10.3$ & $23.7 \pm 9.6$ & $<0.001$ \\
\hline $\mathrm{e} / \mathrm{a}(\mathrm{n} / \mathrm{n})$ & $1.1 \pm 0.5$ & $1.1 \pm 0.7$ & $1.0 \pm 0.5$ & $1.2 \pm 0.5$ & 0.372 & $1.1 \pm 0.5$ & $1.3 \pm 0.5$ & 0.051 \\
\hline
\end{tabular}

SD — standard deviations; PCI — percutaneous coronary intervention; CABG — coronary artery bypass surgery; CS — clinically significant difference; NS - clinically not significant difference; BMI — body mass index; ALT — alanine aminotransferase in IU/L at $37^{\prime} \mathrm{C}$, AST - aspartate aminotransferase in IU/L at 37' C, GGT — gamma glutamyltransferase in IU/L at 37' C, HDL high density lipoprotein; LDL — low density lipoprotein; LVEDD — left ventricle end diastolic dimension; LVEF — left ventricle ejection fraction; AV PG — aortic valve peak flow gradient. 
Table 3. General cardiovascular drugs

\begin{tabular}{|c|c|c|c|c|c|c|c|c|}
\hline & \multicolumn{3}{|c|}{ Treatments } & \multirow{2}{*}{$\begin{array}{c}\text { Kruskal Wallis } \\
\text { ANOVA by } \\
\text { ranks }\end{array}$} & \multicolumn{2}{|c|}{ Disease } & \multirow[b]{2}{*}{ Chi square } \\
\hline & & $\begin{array}{c}\text { Conservative } \\
\mathrm{N}(\%)\end{array}$ & $\begin{array}{c}\mathrm{PCI} \\
\mathrm{N}(\%)\end{array}$ & $\begin{array}{l}\text { Surgery } \\
\mathrm{N}(\%)\end{array}$ & & $\begin{array}{l}\text { Ischemic } \\
\mathrm{N}(\%)\end{array}$ & $\begin{array}{l}\text { Valvular } \\
\mathrm{N}(\%)\end{array}$ & \\
\hline \multicolumn{2}{|c|}{$\begin{array}{l}\text { Angiontensinogen-convertase } \\
\text { inhibitor/sartan } \\
\text { Beta blocker } \\
\text { Calcium antagonist } \\
\text { Loop diuretic } \\
\text { Statin } \\
\text { Omega-3/fibrate } \\
\text { Nitrate (sublingval and peroral) } \\
\text { Trimetazidine } \\
\text { Proton pump inhibitor } \\
\text { Oral antidiabetics } \\
\text { Insuline }\end{array}$} & $\begin{array}{l}7(87.5 \%) \\
7(87.5 \%) \\
3(37.5 \%) \\
4(50.0 \%) \\
8(100.0 \%) \\
3(37.5 \%) \\
4(50.0 \%) \\
5(62.5 \%) \\
7(87.5 \%) \\
2(25.0 \%) \\
1(12.5 \%)\end{array}$ & $\begin{array}{c}35(83.3 \%) \\
40(95.2 \%) \\
8(19.0 \%) \\
8(19.0 \%) \\
40(95.2 \%) \\
26(61.9 \%) \\
30(71.4 \%) \\
3(7.1 \%) \\
10(23.8 \%) \\
8(19.0 \%) \\
3(7.1 \%)\end{array}$ & $\begin{array}{c}17(37.0 \%) \\
34(73.9 \%) \\
4(8.7 \%) \\
13(28.3 \%) \\
22(47.8 \%) \\
3(6.5 \%) \\
4(8.7 \%) \\
1(2.2 \%) \\
30(65.2 \%) \\
5(10.9 \%) \\
2(4.3 \%)\end{array}$ & $\begin{array}{c}<0.001 \\
0.023 \\
0.086 \\
0.171 \\
<0.001 \\
<0.001 \\
<0.001 \\
<0.001 \\
<0.001 \\
0.432 \\
0.649\end{array}$ & $\begin{array}{c}51(66.2 \%) \\
68(88.3 \%) \\
14(18.2 \%) \\
20(26.0 \%) \\
66(85.7 \%) \\
31(40.3 \%) \\
38(49.4 \%) \\
9(11.7 \%) \\
36(46.8 \%) \\
15(19.5 \%) \\
6(7.8 \%)\end{array}$ & $\begin{array}{c}8(42.1 \%) \\
13(68.4 \%) \\
1(5.3 \%) \\
5(26.3 \%) \\
4(21.1 \%) \\
1(5.3 \%) \\
0(0.0 \%) \\
0(0.0 \%) \\
11(57.9 \%) \\
0(0.0 \%) \\
0(0.0 \%)\end{array}$ & $\begin{array}{c}0.053 \\
0.032 \\
0.165 \\
0.976 \\
<0.001 \\
0.004 \\
<0.001 \\
0.117 \\
0.384 \\
0.036 \\
0.209\end{array}$ \\
\hline \multicolumn{2}{|c|}{$\begin{array}{l}\text { Acetilsalycilate (ASA) } \\
\text { Thienopyridine (T) } \\
\text { Warfarin }\end{array}$} & $\begin{array}{c}7(87.5 \%) \\
7(87.5 \%) \\
0(0.0 \%)\end{array}$ & $\begin{array}{c}36(85.7 \%) \\
27(64.3 \%) \\
0(0.0 \%)\end{array}$ & $\begin{array}{l}36(78.3 \%) \\
28(60.9 \%) \\
24(52.2 \%)\end{array}$ & $\begin{array}{c}0.610 \\
0.351 \\
<0.001\end{array}$ & $\begin{array}{c}64(83.1 \%) \\
49(63.6 \%) \\
8(10.4 \%)\end{array}$ & $\begin{array}{l}15(78.9 \%) \\
13(68.4 \%) \\
16(84.2 \%)\end{array}$ & $\begin{array}{c}0.670 \\
0.696 \\
<0.001\end{array}$ \\
\hline \multicolumn{2}{|c|}{$\begin{array}{ll}\text { AP-combinations } & \begin{array}{l}\text { Acet1lsalycilate } \\
\text { Clopidrogel } \\
\\
\text { Dual AP }\end{array} \\
\end{array}$} & $\begin{array}{c}1(12.5 \%) \\
0(0.0 \%) \\
0(0.0 \%) \\
7(87.5 \%)\end{array}$ & $\begin{array}{c}5(11.9 \%) \\
10(23.8 \%) \\
1(2.4 \%) \\
26(61.9 \%)\end{array}$ & $\begin{array}{c}9(19.6 \%) \\
9(19.6 \%) \\
1(2.2 \%) \\
27(58.7 \%)\end{array}$ & 0.369 & $\begin{array}{c}11(14.3 \%) \\
17(22.1 \%) \\
2(2.6 \%) \\
47(61.0 \%)\end{array}$ & $\begin{array}{c}4(21.1 \%) \\
2(10.5 \%) \\
0(0.0 \%) \\
13(68.4 \%)\end{array}$ & 0.552 \\
\hline \multirow[t]{3}{*}{$\begin{array}{l}\text { Warfarin }+ \\
\text { AP-combinations }\end{array}$} & $\begin{array}{l}\text { None } \\
\text { Warfarine } \\
\text { Triple } \\
\text { Warfarine + AP }\end{array}$ & $\begin{array}{c}8(100.0 \%) \\
0(0.0 \%) \\
0(0.0 \%) \\
0(0.0 \%)\end{array}$ & $\begin{array}{c}42(100.0 \%) \\
0(0.0 \%) \\
0(0.0 \%) \\
0(0.0 \%)\end{array}$ & $\begin{array}{c}22(47.8 \%) \\
6(13.0 \%) \\
4(8.7 \%) \\
14(30.4 \%)\end{array}$ & $<0.001$ & $\begin{array}{l}69(89.6 \%) \\
3(3.9 \%) \\
2(2.6 \%) \\
3(3.9 \%)\end{array}$ & $\begin{array}{c}3(15.8 \%) \\
3(15.8 \%) \\
2(10.5 \%) \\
11(57.9 \%)\end{array}$ & $<0.001$ \\
\hline & & Mean \pm SD & Mean \pm SD & Mean \pm SD & $\begin{array}{c}\text { Kruskal Wallis } \\
\text { ANOVA by } \\
\text { ranks }\end{array}$ & Mean \pm SD & Mean \pm SD & $\begin{array}{c}\text { Mann } \\
\text { Whitney U } \\
\text { test }\end{array}$ \\
\hline & $\begin{array}{l}\mathrm{N} \text { (drugs) } \\
\text { Antiplatelts (\%) } \\
\text { Warfarin (\%) } \\
\text { AP+Warfarin (\%) }\end{array}$ & $\begin{array}{c}8.1 \pm 2.0 \\
11.8 \pm 5.4 \\
0.0 \pm 0.0 \\
0.0 \pm 0.0\end{array}$ & $\begin{array}{c}6.5 \pm 1.5 \\
16.4 \pm 5.0 \\
0.0 \pm 0.0 \\
0.0 \pm 0.0\end{array}$ & $\begin{array}{c}4.8 \pm 1.3 \\
13.4 \pm 10.8 \\
11.5 \pm 12.1 \\
8.7 \pm 16.2\end{array}$ & $\begin{array}{c}<0.001 \\
0.308 \\
<0.001 \\
0.001\end{array}$ & $\begin{array}{c}6.2 \pm 1.7 \\
16.3 \pm 6.7 \\
1.8 \pm 5.5 \\
3.3 \pm 10.7\end{array}$ & $\begin{array}{c}4.6 \pm 1.5 \\
7.4 \pm 10.8 \\
20.4 \pm 11.0 \\
7.8 \pm 16.1\end{array}$ & $\begin{array}{c}<0.001 \\
0.001 \\
<0.001 \\
0.146\end{array}$ \\
\hline
\end{tabular}

SD — standard deviations; $\mathbf{n}$ — number; CABG — coronary artery bypass surgery; VS — valvular surgery; AP — antiplatelets; ASA - Acetylsalicylate acid; T - Thienopyridine

were no differences in studied platelets regimens for studied groups of treatment and disease etiology, while regimens that included peroral anticoagulant therapy showed significant differences in both studied categories.

Drug utilization analyzes for common cardiovascular group of drugs was studied in connection with type of previous cardiovascular treatment (percutaneous coronary interventions or surgery-coronary artery bypass graft and/or valvular surgery) and etiology of heart disease (ischemic or valvular). According to type of cardiovascular treatment, there were significant differences for angiontensinogen-convertase inhibitor/sartan; beta blockers, antilipid drugs, antianginals and warfarin. On the other hand, when etiology of heart disease was studied, significant differences were found for beta blockers, nitrates, antilipid drugs, peroral antidiabetics and warfarin.

Relative shares of specific representatives and drug combinations of all studied group of drugs and their combinations are shown in the Table 3.
During the study course, we did not have any case of clinically significant bleeding (intracerebral, pericardial, pleural, abdominal, and gastrointestinal) and no blood transfusions. Cases of bleeding associated with surgical treatment complications (early complications, in first postoperative week) that had to be managed by surgery were not included in the study.

\section{DISCUSSION}

Current study for the first time systematically analyzed utilization of antiplatelets and anticoagulant group in patients with secondary prevention and rehabilitation from Croatia. Share of antiplatelets agents was in range from $10-17 \%$, while peroral anticoagulants made about $12 \%$ of total prescriptions. Relative portions of antiplatelet and anticoagulant group were greater in the postsurgical group, which in part represents suspected underutilization of antilipemics, beta blockers and angiotensin-convertase inhibitors/sartans; pa- 
rallel with decrease in total number of drugs per patient (8). Consumption of antiplatelets was greater in the group of patients with ischemic heart disease, conversely to the warfarin which was more commonly used with valvular operations. Additional factor that favored peroral anticoagulants was presence of atrial fibrillation which was pounded more frequently in surgical patients, especially ones with ischemic heart disease. Interestingly, there were no differences in consumption of antiplatelets or their combinations within studied groups of cardiovascular treatment or the etiology of heart disease. Warfarin and its combinations showed to be plentifully related with cardiovascular treatment, as well as through etiology of heart disease. Relations of anticoagulant therapy with laboratory parameters seem to represented acute treatments backgrounds i.e. greater prevalence of surgical treatments, than the effects of therapy per se.

Consumption of acetylsalicylate acid varied from $87.5 \%$ of conservative treatments down to $78.3 \%$ in surgical and was of similar ranges between the ischemic heart disease and valvular. Rate of underutilization for acetylsalicylates was $13 \%$ for the ischemic group. Low dose acetylsalicylic acid (ASA) (75-100 mg) acts as irreversible inhibitor of the cyclooxygenase-1 (COX-1) in platelets (9). Additional mechanisms that might exhibit the cardiovascular protection include anti-inflammatory and tissue remodeling/reparation effects by inhibition of the expression of inducible nitrous oxidase (INOS), inhibition of activation of nuclear factor kappa-beta (NF-kB), with initiation of acute phase response and inhibition of neutrophil activation $(10,11)$. Large scale meta-analysis reported on beneficiary effects of acetylsalicylic acid in primary prevention of serious adverse atherothrombotic complications, pointing out the prevalence of first non-fatal myocardial infarction, stroke, cardiovascular death (12). Furthermore, owing to conceptualization shift to preventive actions in the "cardiovascular continuum" ASA is now-days recommended therapy by evidence based merits for patients that did not survive the cardio-cerebro-vascular or peripheral artery event, nonetheless bear the increased scores of 10-years cardiovascular hazard due to prevalence of combined risk factors or chronic comorbidities, particularly diabetes $(13,14)$. Over and above, the group of individuals with arterial hypertension of high risk grade also showed long-term benefits in preventive therapy with acetylsalicylate acid (15). Secondary prevention considers the lifelong therapy with antithrombotic agent, outlining only the importance for remaining short and long term patency of the implanted intracoronary stent or coronary bypass grafts $(16,17)$. Despite the predictable complications, dominantly in terms of gastric and enteric mucosal lesions, nephro- pathy and salicylism in the adults, underutilization of acetylsalicylate acid is commonly found in clinical practice (18). The latter was predicted to save up to 10.000 of lives each year in the population of 350 million, if the theoretical sustained coverage would be equal to entire set of patients surviving the acute coronary syndrome (19). Another important problem is around acetylsalicylate acid lesser treatment efficiency i.e. aspirin resistance, which could be of clinical and laboratory types. Latter could happen in relation with patients' characteristics (alternation in platelets production or function, genetic alternations in metabolism of drugs, diabetes mellitus, nicotinismus, some food and beverages as grape juice or alcohol), and drug-drug interactions (with non-steroidal anti-inflammatory drugs, some type of statins, and proton pump inhibitors) $(20,21,22,23)$. Similar scenarios occur with other antiplatelet drugs, as well as their combinations $(24,25)$.

Dual antiplatelet therapy consisting of ASA and Clopidogrel was the most commonly used antiplatelet modality in our patients, making $62 \%$ in ischemic heart disease, and of nearly equal ranges among studied groups of cardiovascular treatments (26). Clopidogrel is irreversible thienopyridine blocker of P2Y12 protein, adenosine diphosphate (ADP) chemoreceptor on platelet cell membranes (27). Drug is used for prevention of thromboembolic events such as cerebrovascular stroke, peripheral artery disease or acute coronary syndrome, as well as for improvement of the short and long term patency of implanted intracoronary stents (28, $29)$. Increased consumption of dual antiplatelet combinations in $57 \%$ of surgical patients and $68 \%$ of valvular, might be prominently explained through prevalence of atherothrombotic disorders and atrial fibrillation in these groups. Benefits of dual antiplatelet therapy in remaining of the bare metal stent patency beyond the period of 6-12 months are less evident; however future studies comprising of populations with surgical revascularization, prevalence of comorbidities and the extent of atherosclerotic process would be valuable in order to increase the cost-efficiency (30).

Position of peroral anticoagulant therapy with antagonist of the $\mathrm{K}$ vitamin in secondary prevention of cardiovascular diseases is still matter of consultations due to unanimous conclusions (31). Studies showed lack of coherence in evidences about net benefit in major cardiovascular events versus bleeding which was mainly corresponding with the dosing regiments i.e. attained levels of international normalized ratios (INR) (32). Supplementary controversies of vitamin K antagonists could be found in the reported advancement in atherosclerosis or thrombus stability through inhibition of matrix Gla-protein (MGP) and subsequent vascular calcification $(32,33)$. The triple combination also 
brings certain challenges and questions in terms of legislative. Although some professional societies recommend triple therapy in some instances, the labeling directives of drugs, produced by various companies do not imply preferring the use of such combinations due to similar safety concerns (bleeding risk).

Although the study settings represent the non-randomized cohort of patients on cardiovascular rehabilitation, most of the comorbidities were found to be of similar national prevalence within earlier reports (33, 34). Most of risk factors from the modifiable cluster were still found to be of high prevalence, particularly continuous nicotine abuse in $36 \%$ of patients. In addition, $23 \%$ of patients were obese and $58 \%$ overweight, diabetes $26 \%$, glucose intolerance $35 \%$, metabolic syndrome $66 \%$, and chronic renal disease $45 \%(6,35)$.

In conclusion, utilization of acetylsalicylate acid therapy was found to be of similar range in compare with the most developed industrial nations. Dual antiplatelet therapy was the most common prescription routine. Triple therapy was used to less degree, in patients of secondary or tertiary prevention, mostly ones with atrial fibrillation. Acute settings cardiovascular treatment was shown to influence the prescription routine, apart from heart disease etiology, raising concerns about the decreased use of available pharmacological agents in secondary prevention of the post-surgical patients.

\section{Conflict of interest:}

None declared

\section{Acknowledgments:}

This study was not supported financially in any way.

\section{Abbreviations:}

AP - antiplatelets

COPD - chronic obstructive pulmonary disease

AC - anticoagulants

CRD - chronic renal disease

ASA - Acetylsalicylate acid

LVEF - left ventricle ejection fraction (\%)

T - Thienopyridine

ERC - eritrocytes

PCI - percutaneous coronary intervention

HCT - hematocrit

CABG - coronary artery bypass surgery

MCV - mean corpuscular volume of erythrocytes

VS - valvular surgery

LKC - leukocytes

BMI — body mass index $(\mathrm{kg} / \mathrm{m} 2)$

PLT - platelets

WC - waist circumference $(\mathrm{cm})$

GLC - serum glucose

HC - hip circumference $(\mathrm{cm})$

CREAT - creatinine

WHR - waist-hip ratio

CHOL - cholesterol

HDL — high density lipoprotein

LDL — low density lipoprotein

\title{
Sažetak
}

\section{ANALIZA KORIŠTENJA ANTITROMBOCITNIH LEKOVA I PERORALNE ANTIKOAGULANTNE TERAPIJE KOD BOLESNIKANA STACIONARNOM PROGRAMU BOLNIČKE KARDIOLOŠKE REHABILITACIJE}

\author{
Boban Marko, ${ }^{1,2}$ Persic Viktor, ${ }^{1,2}$ Pesa Vladimir, ${ }^{1}$ Pehar-Pejcinovic Vesna, ${ }^{1}$ Detanac S. Dzemail, ${ }^{3}$ \\ Sipic Tomislav, ${ }^{2}$ Zulj Marinko, ${ }^{2}$ Franovic Tamara, ${ }^{1}$ Vcev Aleksandar ${ }^{2}$ \\ ${ }^{1}$ Department of cardiology, University hospital "Thalassotherapia Opatija”, Medical faculty University of Rijeka; Croatia \\ ${ }^{2}$ Department of internal medicine, Medical faculty JJ Strossmayer, Osijek, Croatia \\ ${ }^{3}$ General hospital Novi Pazar, Serbia
}

Uvod: Neslaganje sa smernicama i neoptimizacija farmakoterapije u sekundarnoj prevenciji često postoji u kliničkoj praksi. Cilj istraživanja bio je proceniti obrazac propisivanja i utilizacije antitrombocitnih lekova i peroralne antikoagulantne terapije u tercijarnom medicinskom centru specijalizovanom za kardiovaskularnu rehabilitaciju.

Metode: u studiju je uključeno 96 uzastopnih bolesnika zakazanih za kardiovaskularnu rehabilitaciju u razdoblju od 1 do 6 meseci nakon akutnog lečenja zbog ishemijske bolesti srca $(80,2 \%)$ i bolesti srčanih zalistaka (19,8\%). Bolesnici su podeljeni prema etiologiji bolesti srca i akutnim oblicima lečenja.

Rezultati: Dvojna antiagregaciona terapija bila je najčešće korišćeni režim kod 87,5\% konzervativno lečenih infarkta miokarda, 61,9\% perkutane koronarne intervencije (PCI) i 58,9\% kod hirurški tretirane grupe $(p>0,05)$. Profil utilizacije nije bio značajno različit za 
antitrombocitne lekove ( $\mathrm{p}>0,05)$; Obrnuto, utilizacija varfarina, ili kombinacije koje su uključivale varfarin, značajno su se razlikovale prema ispitivanim grupama lečenja ( $\mathrm{p}<0.001)$ i etiologiji bolesti $(\mathrm{p}<0,001)$. Sva četiri bolesnika koja su primila trostruku terapiju $(4,17 \%)$ bila su u grupi hirurški lečenih pacijenata. Neadekvatna utilizacija antitrombocitnih lekova u ishemijskoj bolesti srca iznosila je 14,3\%, što je u skladu sa razvijenim industrijskim zemljama.

Zaključak: Vrsta akutnog kardiološkog lečenja u značajnoj je meri određivala naknadno korišćenje le-

\section{REFERENCES}

1. Meade T. Primary prevention of ischaemic cardiovascular disorders with antiplatelet agents. Handb Exp Pharmacol. 2012; (210): 565-605.

2. Toscani MR, Makkar R, Bottorff MB. Quality improvement in the continuum of care: Impact of atherothrombosis in managed care pharmacy. J Manag Care Pharm. 2004; $10(6$ Suppl A): S2-12; quiz S13-16.

3. Ho WK, Hankey GJ, Eikelboom JW. Prevention of coronary heart disease with aspirin and clopidogrel: Efficacy, safety, costs and cost-effectiveness. Expert Opin Pharmacother. 2004; 5(3): 493-503.

4. Bhatt DL, Chew DP, Hirsch AT, Ringleb PA, Hacke W, Topol EJ. Superiority of clopidogrel versus aspirin in patients with prior cardiac surgery. Circulation. 2001; 103(3): 363-8.

5. Sambola A, Ferreira-Gonzalez I, Angel J, et al. Therapeutic strategies after coronary stenting in chronically anticoagulated patients: The musica study. Heart. 2009; 95(18): 1483-8.

6. Kotseva K, Wood D, De Backer G, et al.Euroaspire III. A survey on the lifestyle, risk factors and use of cardioprotective drug therapies in coronary patients from 22 european countries. Eur J Cardiovasc Prev Rehabil. 2009; 16(2): 121-37.

7. Lang RM, Badano LP, Mor-Avi V, et al. Recommendations for cardiac chamber quantification by echocardiography in adults: An update from the american society of echocardiography and the european association of cardiovascular imaging. European heart journal cardiovascular Imaging. 2015; 16(3): 233-71.

8. Griffo R, Ambrosetti M, Tramarin R, Fattirolli F, Temporelli PL, Vestri AR, et al. Effective secondary prevention through cardiac rehabilitation after coronary revascularization and predictors of poor adherence to lifestyle modification and medication. Results of the icaros survey. Int J Cardiol. 2013; 167(4): 1390-5.

9. Patrono C, Baigent C. Low-dose aspirin, coxibs, and other nsaids: A clinical mosaic emerges. Mol Interv. 2009; 9(1): 31-9.

10. Amin AR, Vyas P, Attur M, et al. The mode of action of aspirin-like drugs: Effect on inducible nitric oxide synthase. Proc Natl Acad Sci USA. 1995; 92(17): 7926-30.

11. Kopp E, Ghosh S. Inhibition of nf-kappa b by sodium salicylate and aspirin. Science. 1994; 265(5174): 956-9.

12. Baigent C, Blackwell L, Collins R, et al. Aspirin in the primary and secondary prevention of vascular disease: Collaborative meta-analysis of individual participant data from randomised trials. Lancet. 2009; 373(9678): 1849-60.

13. Hennekens CH, Knatterud GL, Pfeffer MA. Use of aspirin to reduce risks of cardiovascular disease in patients with kova, nasuprot etiologiji bolesti srca. Zapaženo je suboptimalno korišćenje lekova sekundarne prevencije kod grupe hirurških bolesnika. Analiza potrošnje lekova može pomoći kod optimizacije terapije, unapređenja kvaliteta zdravstvene nege, smanjenja polipragmazije, te poboljšanja ekonomske efikasnosti medicinskog lečenja.

Ključne reči: analiza utilizacije farmakoterapije; antitrombocitna terapija; antikoagulantna terapija; varfarin; kardiovaskularna rehabilitacija; ishemijska bolest srca; bolesti srčanih zalistaka.

diabetes: Clinical and research challenges. Diabetes Care. 2004; 27(11): 2752-4.

14. Tufano A, Cimino E, Di Minno MN, et al. Diabetes mellitus and cardiovascular prevention: The role and the limitations of currently available antiplatelet drugs. Int J Vasc Med. 2011; 2011: 250518.

15. Mancia G, De Backer G, Dominiczak A, et al. $2007 \mathrm{gu}-$ idelines for the management of arterial hypertension: The task force for the management of arterial hypertension of the european society of hypertension (esh) and of the european society of cardiology (esc). J Hypertens. 2007; 25(6): 1105-87.

16. Mangano DT. Aspirin and mortality from coronary bypass surgery. N Engl J Med. 2002; 347(17): 1309-17.

17. Kushner FG, Hand M, Smith SC, Jr., et al. 2009 focused updates: Acc/aha guidelines for the management of patients with st-elevation myocardial infarction (updating the 2004 guideline and 2007 focused update) and acc/aha/scai guidelines on percutaneous coronary intervention (updating the 2005 guideline and 2007 focused update) a report of the american college of cardiology foundation/american heart association task force on practice guidelines. J Am Coll Cardiol. 2009; 54(23): 2205-41.

18. Hennekens CH, Schneider WR. The need for wider and appropriate utilization of aspirin and statins in the treatment and prevention of cardiovascular disease. Expert Rev Cardiovasc Ther. 2008; 6(1): 95-107.

19. Hennekens CH, Jonas MA, Buring JE. The benefits of aspirin in acute myocardial infarction. Still a well-kept secret in the united states. Arch Intern Med. 1994; 154(1): 37-9.

20. Tantry US, Gesheff M, Liu F, Bliden KP, Gurbel PA. Resistance to antiplatelet drugs: what progress has been made? Expert Opin Pharmacother. 2014; 15(17): 2553-64.

21. Petricevic M, Milicic D, White A, et al. Development of a concept for a personalized approach in the perioperative antiplatelet therapy administration/discontinuation management based on multiple electrode aggregometry in patients undergoing coronary artery surgery. J Thromb Thrombolysis. 2015; 40(3): 383-91.

22. Floyd CN, Ferro A. Mechanisms of aspirin resistance. Pharmacol Ther. 2014; 141(1): 69-78.

23. Petricevic M, Biocina B, Boban M, et al. Clinical Relevance and Practical Value of Platelet Function Assessment Using Multiple Electrode Aggregometry during Extracorporeal Circulation. Thorac Cardiovasc Surg. 2015; 63(4): 351-2.

24. Floyd CN, Ferro A. Antiplatelet drug resistance: Molecular insights and clinical implications. Prostaglandins Other Lipid Mediat. 2015; 120: 21-7. 
25. Bhatt DL, Fox KA, Hacke W, et al. Clopidogrel and aspirin versus aspirin alone for the prevention of atherothrombotic events. N Engl J Med. 2006; 354(16): 1706-17.

26. Foster CJ, Prosser DM, Agans JM, et al. Molecular identification and characterization of the platelet adp receptor targeted by thienopyridine antithrombotic drugs. J Clin Invest. 2001; 107(12): 1591-8.

27. Sharis PJ, Cannon CP, Loscalzo J. The antiplatelet effects of ticlopidine and clopidogrel. Ann Intern Med. 1998; 129(5): 394- 405.

28. Steinhubl SR, Berger PB, Brennan DM, Topol EJ. Optimal timing for the initiation of pre-treatment with $300 \mathrm{mg}$ clopidogrel before percutaneous coronary intervention. J Am Coll Cardiol. 2006; 47(5): 939-43.

29. Valgimigli M, Campo G, Monti M, et al. Short- versus long-term duration of dual-antiplatelet therapy after coronary stenting: Arandomized multicenter trial. Circulation. 2012; 125(16): 2015-26.

30. Hylek EM, Solarz DE. Dual antiplatelet and oral anticoagulant therapy: Increasing use and precautions for a hazardous combination. JACC Cardiovasc Interv. 2008; 1(1): 62-4.
31. Andreotti F, Testa L, Biondi-Zoccai GG, Crea F. Aspirin plus warfarin compared to aspirin alone after acute coronary syndromes: An updated and comprehensive meta-analysis of 25,307 patients. Eur Heart J. 2006; 27(5): 519-26.

32. Schurgers Lj, Dissel PE, Spronk HM, et al. Role of vitamin $\mathrm{k}$ and vitamin $\mathrm{k}$-dependent proteins in vascular calcification. Z Kardiol. 2001; 90 (Suppl 3): 57-63.

33. Rothberg MB, Celestin C, Fiore LD, Lawler E, Cook JR. Warfarin plus aspirin after myocardial infarction or the acute coronary syndrome: Meta-analysis with estimates of risk and benefit. Ann Intern Med. 2005; 143(4): 241-50.

34. Reiner Z, Mihatov S, Milicic D, Bergovec M, Planinc D. Treatment and secondary prevention of ischemic coronary events in croatia (taspic-cro study). Eur J Cardiovasc Prev Rehabil. 2006; 13(4): 646-54.

35. Vrazic H, Sikic J, Lucijanic T, et al. The prevalence of overweight and obesity among croatian hospitalized coronary heart disease patients. Coll Antropol. 2012; 36 (Suppl 1): 211-6.

\section{Correspondence to / Autor za korespondenciju}

Assist. Prof. Marko Boban, MD, PhD, MBA

Department of cardiology. University Hospital Thalassotherapia Opatija

Medical Faculty University of Rijeka

Medical faculty JJ Strossmayer, Osijek, Croatia

E-mail:marcoboban@yahoo.com

M. Tita 188/1; Opatija 51 440; Croatia;

Mob: ++385 51202 600; Fax: ++385 51271424 